\title{
PROCEEDING
}

\section{Human nutritional science on stress control}

\author{
Eiji Takeda \\ The 21 st Century COE Program "Human nutritional science on stress control" , Institute of \\ Health Biosciences, The University of Tokushima Graduate School, Tokushima, Japan
}

\begin{abstract}
Severe and prolonged stress exposure impairs homeostatic mechanisms, particularly associated with the onset of depressive illness. The establishment of functional foods that correctly regulate stress response must be an important and new field for human nutrition. This exciting science has been vigorously achieving in the $21^{\text {st }}$ century COE program of University of Tokushima Graduate School. J.Med. Invest. 52 Suppl. :223-224, November, 2005
\end{abstract}

Keywords : stress, nutrition, functional food

\section{STRESSFUL SOCIETY}

The proportion of senior citizens and children in relation to the general population is rapidly increasing and continuously decreasing, respectively, in Japan. Today the percentage of people over 65 in Japan is approximately $17 \%$. With the development of an unbalanced and senior society, human activities and lifestyles generate numerous forms of environmental stress. This outstanding level of stress is certainly reflected by the number of Japanese people (more than 30,000 ) who commit suicide, and mental and physical disorders caused by stress are serious social and economic problems.

Stressful life events may contribute to the onset and course of mood deterioration and affective disorders such as depression $(1,2)$. Stress is a pervasive factor in everyday life that critically affects development and functioning. It has been hypothesized that stress exposure has important adaptive consequences by enhancing neurobehavioral ontogeny for virtually all animal species (3). However, severe and prolonged stress exposure impairs homeostatic mechanisms that can aversively affect functioning

Received for publication September 9, 2005 ; accepted September $16,2005$.

Address correspondence and reprint requests to Eiji Takeda, M.D., Ph. D., Department of Clinical Nutrition, Institute of Health Biosciences, The University of Tokushima Graduate School, Kuramoto-cho, Tokushima770-8503, Japan and Fax:+81-886337094. of multiple organ systems. Stress appears to play a major role in the pathophysiology of nearly all psychiatric disorders particularly depressive illness(4-9).

\section{FUNCTIONAL FOOD}

Food environment, such as eating styles or nutrients, greatly affects mental health especially in children and teenager. The need for medical treatment is expected to increase, but in many cases it may not improve the quality of life. Therefore, the goal of functional foods is to improve or maintain quality of life in mental health before medical treatment is required. The concept of functional food, particularly brain food, still has left much room for scientific arguments by professionals. Brain food is aimed at modifying genetic and psychological aspects of human life, and preventing as well as treating a growing number of stress-related mental disorders. The establishment of functional foods that correctly regulate stress response must be firmly based upon scientific knowledge and legal regulation. Therefore, efficient biomarkers related to pathological stress responses must be found. Furthermore, it is indispensable to conduct valid studies on humans.

\section{THE $21^{\text {st }}$ CENTURY COE PROGRAM}




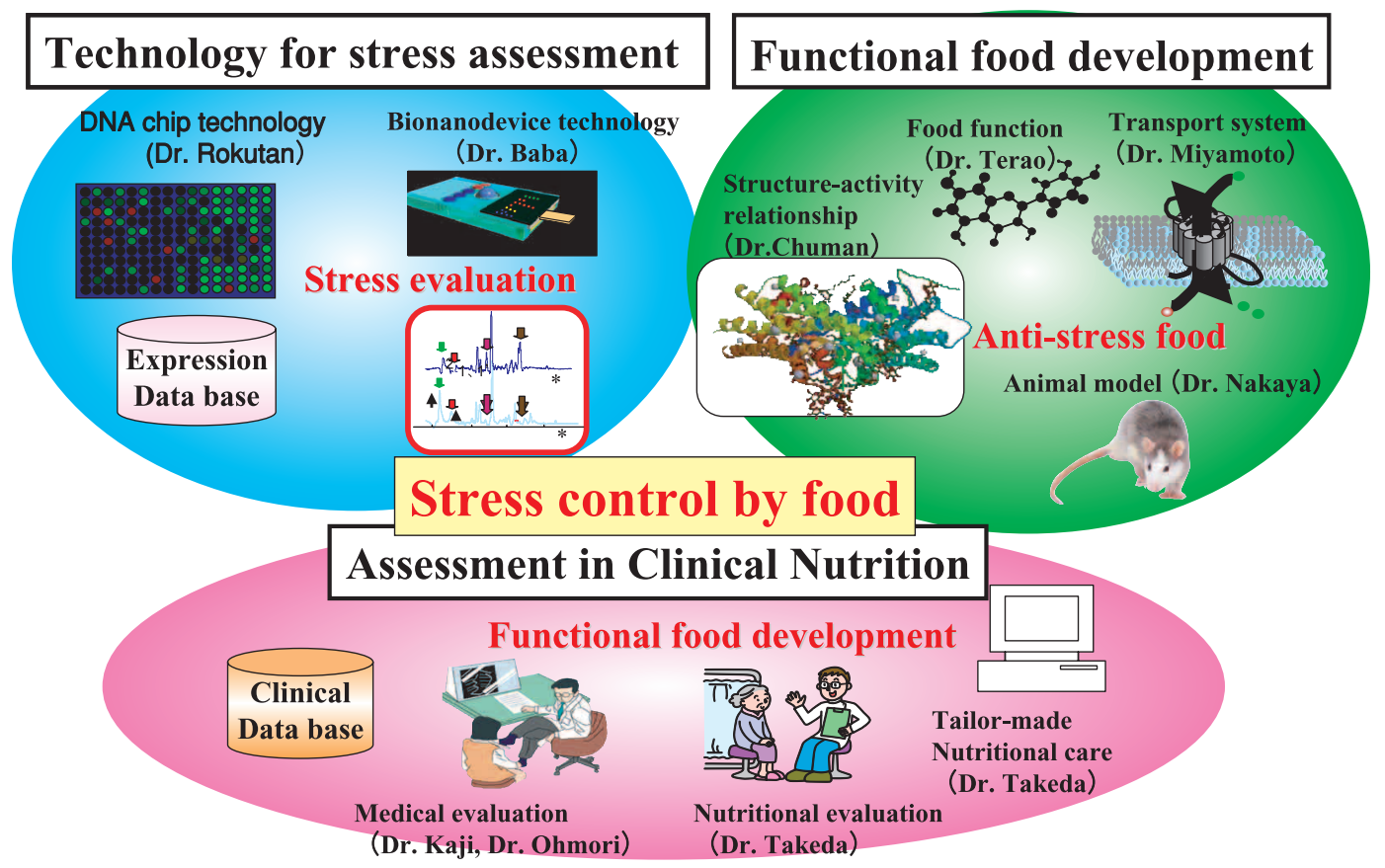

Figure. Strategy of COE program

The goals of the $21^{\text {st }}$ century COE program "Human Nutritional Science on Stress Control" in University of Tokushima Graduate School are to develop a novel scientific field for human nutrition in stress research and to employ these strategies to examine the functions of foods on human mind (Figure). We have developed a novel method that makes it possible to simply, objectively evaluate human stress response using a microarray technique. Particularly, we have succeeded in detecting a gene expression profile characteristic of major depression in peripheral blood leukocytes. At the same time, we have been developing "nanobiodevices" to promptly measure these maker gene products. Based on our stateofthe-art technologies and outstanding achievements in human nutrition, this COE program will definitely meet the demands of society by establishing a new "biomental" technique to objectively measure pathological stress responses, introducing brain foods that correctly regulate stress responses, and developing an integrated system to open a new field of research.

\section{REFERENCES}

1. Brawn GW, Bifulco A, Harris TO : Life events, vulnerability and on-set of depression : some refinements. Br J Psychiatry 150 : 30-42, 1987

2. Cooke DJ, Hole DJ : The etiological importance of stressful life events. Br J Psychiatry 143 : 397-400, 1983

3. Selye $\mathrm{H}$ : The stress concept today. In: Dutash IL, Schlesinger LB (eds), Handbook of Stress and Anxiety. Jossey-Bass Inc., London, pp 127143, 1980

4. Paykel ES, Myers JK, Dienelt MN, Klerman GL, Lindenthal JJ, Pepper MP:Life events and depression: A controlled study. Arch Gen Psychiatry $21: 753-760,1969$

5. Leff MJ, Roatch JF, Bunney WE: Environmental factors preceding the onset of severe depression. Psychiatry 33 : 298-311, 1970

6. Thompson K, Hendric H:Environmental stress in primary depressive illness. Arch Gen Psychiatry $26: 130-132,1972$

7. Brown GW, Harris TO, Peto J:Life events and psychiatric disorders. II. Nature of causal links. Psychol Med 3 : 159-176, 1973

8. Goodwin FK, Bunney WE : Psychobiological aspects of stress and affective illness. In:Scott JP, Senay EC (eds), Separation and Aggression: Clinical and Research Aspects. AAAS, Washington DC, 1973

9. Lloyd C : Life events and depressive disorder reviewed. I. Events as predisposing factors. Arch Gen Psychiatry 37 : 529-535, 1980 